\title{
RECENT TRENDS IN LIBRARY AND INFORMATION SCIENCE RESEARCH: WITH SPECIAL REFERENCE TO INDIA
}

\section{DR. SANTOSH DNYANOBARAO KADAM \& MR. SHANKAR CHANDRAKANT BHUSAWAR}

Librarian, Vasantrao Naik Marathwada Krishi Vidyapeeth, Parbhani, Maharastra, India

Librarian, CSMSS Chh. Shahu College of Engineering, Aurangabad, Maharastra, India

\begin{abstract}
Efforts were made to find out the research trends in Library and Information Science in India in the last decade. Publication trend in the top five Indian LIS journals is analyzed with the help of 2414 articles published in the last decade. The 1288 LIS Ph.D thesis were analyzed according to their area of research. The results of the study show that the subjects Information Communication Technology, Information Science and bibliometrics/scientometrics/webometrics attracted more authors for writing the research papers. Where as user study, e-Resources and Information Communication Technology were the top ranking research areas chosen by the research scholars for their doctoral research. The subjects classification and cataloguing were the most ignored research areas.

KEYWORDS: Library, Information, Communication \& Research Papers
\end{abstract}

Received: Apr 15, 2020; Accepted: May 06, 2020; Published: May 26, 2020; Paper Id.: IJLSRJUN20202

\section{INTRODUCTION}

The foundation of LIS education in India goes back to 1911. Maharaja Sayajirao Gakewad of the Baroda State invited W. A. Borden to India for imparting professional LIS education and to develop the public library system of the state. Currently, the LIS education is imparted at various levels such as diploma, certificate, degree and research by Indian Universities and institutes.

Research is an important activity for the overall development of a particular discipline/subject. Dr. S. R. Rangnathan was the pioneer of the doctoral research in LIS in India. The foundation of LIS doctoral research in India goes back to 1952 when Delhi University started the first Ph.D course in LIS. Mr. D. B. Krishna Rao was the first registered candidate for Ph.D at Delhi University under the guidance of Dr.S . R. Rangnathan. His research topic was "Facet analysis and depth classification of Agriculture" and he awarded the Ph.D degree in 1957. The second Ph.D degree was awarded by the Panjab University, Chandigarh in 1977.

\section{SELECTED REVIEW OF LITERATURE:}

Some relevant studies which give the insight of the present study are mentioned here. Khanchandani, Vanita (2019) \& Khumbar, Debbarma \& K. Praveen (2019) presented the scenario of LIS education in India with types of courses offered by the LIS schools i.e. diploma, degree and research programs. The authors also discussed opportunities and challenges in LIS education. Singh, Joginder (2018) analyzed the scenario of the current LIS research trends in the North India. He concluded that the preferred topics of offered by the North India LIS schools includes users behavior, Web based resources, Information literacy, Digital libraries, Library Services, Cost effectiveness and Cost Benefit Analysis, Electronic resources, Collection development, Bibliometric study, 
Information Technology, Information resources, Quality Management, Public Libraries. Chauhan, Suresh \& Mahajan, Preeti (2017) carried out a study to measure the quality and quantity of the Indian LIS research output. The results of the study show that the growth in $\mathrm{PhD}$ production does not result in the growth of article publications at international level. The authors found that most of the research was on bibliometric analysis. The authors emphasize the necessity of research on the other areas of LIS also. Garg, K.C. and Sharma, Chetan (2017) analyzed 2428 papers indexed in Indian Citation Index (ICI) during $2004-2015$. The findings of the study shows that the pattern of research output and the annual growth rate of research are highly inconsistent. The authors found that Bibliometrics/Scientometrics as most preferred research topic and it is followed by User Studies. Singh, Shashi Prabha \& Babbar, Parveen (2014) conducted a study on doctoral research in Library and Information Science in India up to 2012. The findings of the study show that LIS doctoral research in India was at low ebb up to 1970s and onwards it was increased decade by decade. The LIS doctoral research in India was increased up to $144 \mathrm{PhDs}$ per year from 2010 to 2012. Mittal, Rekha (2011) carried out a study on the LIS research trends in India by analyzing 4735 descriptors from 1408 journal for the period of Jan.1990 to June 2010 by using co word analysis method to identify core research areas in LIS. The results of the study shows that the LIS research areas moved towards copy right, digital libraries, institutional repositories, CD-ROM databases and Web 2.0, open access, World Wide Web are some of the new burning issues which attracted the researchers. Chandrashekhara, M. and Ramasesh, C.P. (2009) analyzed total 802 doctoral theses submitted to the 24 Indian universities for the period of 1957 to 2008 . The research topics analyzed according to the rank and the results of the study shows that bibliometrics / scientometrics / informatics is the preferred topic of doctoral research among the LIS researchers and it was followed by the Library Management, University Libraries, Information Systems, Information Seeking Behavior etc. LIS Education was ranked on the tenth position.

\section{METHODOLOGY}

The recent trends in LIS research in India was analyzed on the basis of the 2414 articles published in the top five Indian LIS journals and the doctoral thesis submitted to the Indian Universities iabha $\mathrm{n}$ the last decade (2009-2019). The data of the top five Indian LIS journal is collected online and the 2414 articles published in the total 262 issues of the top five Indian Journals in the last decade were analyzed according to their subjects. The data of the $1288 \mathrm{Ph} . \mathrm{D}$ thesis from 103 Indian Universities having submission year between 2009 to 2019 was collected from the Shodhganga: An ETD of Indian thesis and dissertations. The $1288 \mathrm{Ph} . \mathrm{D}$ thesis were analyzed according to the university, state, top ranking subject and emerging research trends.

\section{Scope and Limitations}

The study is limited for the period of 2009 to 2019 . The study is limited to the 2414 journal articles published in the top five Indian LIS journals. The study is also limited to the 1288 doctoral thesis available on the Shodhganga ETD which are having submission year between 2009-2019.

\section{The Source Journals}

The information of the source journals used for the present study and the total number of articles published during the period 2009-2019 is presented in table 1. 
Table 1: The Source Journals

\begin{tabular}{|c|c|c|c|c|c|c|}
\hline S.N & $\begin{array}{l}\text { Name of the } \\
\text { Journal }\end{array}$ & ISSN & Indexed in & Publisher & $\begin{array}{c}\text { Total } \\
\text { Number of } \\
\text { Issues } \\
\text { Published } \\
\text { (2009-2019) } \\
\end{array}$ & $\begin{array}{c}\text { Total } \\
\text { Number of } \\
\text { Articles } \\
\text { Published } \\
(2009-2019) \\
\end{array}$ \\
\hline 01 & $\begin{array}{l}\text { Annals of } \\
\text { Library \& } \\
\text { Information } \\
\text { Studies }\end{array}$ & $\begin{array}{l}0972-5423 \\
\text { (Print) } \\
0975-2404 \\
\text { (Online) } \\
\end{array}$ & $\begin{array}{l}\text { Scopus, WoS, ICI, } \\
\text { LISA, LISTA, } \\
\text { EBSCO, ProQuest }\end{array}$ & $\begin{array}{l}\text { NISCAIR, New } \\
\text { Delhi }\end{array}$ & 44 & 359 \\
\hline 02 & $\begin{array}{l}\text { DESIDOC } \\
\text { Journal of } \\
\text { Library \& } \\
\text { Information } \\
\text { Technology }\end{array}$ & $\begin{array}{l}0974-0643 \\
\text { (Print) } \\
0976-4658 \\
\text { (Online) }\end{array}$ & $\begin{array}{l}\text { SCOPUS, LISA, } \\
\text { LISTA, } \\
\text { EBSCO, WoS, } \\
\text { ProQuest, EBSCO } \\
\text { etc. }\end{array}$ & $\begin{array}{l}\text { DESIDOC, } \\
\text { DRDO, Delhi }\end{array}$ & 66 & 609 \\
\hline 03 & $\begin{array}{l}\text { Library } \\
\text { Herald }\end{array}$ & $\begin{array}{l}0024-2292 \\
\text { (Print) } \\
0976-2469 \\
\text { (Online) }\end{array}$ & $\begin{array}{l}\text { Indian Citation Index, } \\
\text { EBSCO Discovery, } \\
\text { Summon (ProQuest), } \\
\text { Google Scholar etc. }\end{array}$ & $\begin{array}{l}\text { Delhi Library } \\
\text { Association, } \\
\text { New Delhi }\end{array}$ & 44 & 360 \\
\hline 04 & $\begin{array}{l}\text { PEARL } \\
\text { Journal of } \\
\text { Library and } \\
\text { Information } \\
\text { Science }\end{array}$ & $\begin{array}{l}0973-7081 \\
\text { (Print) } \\
0975-6922 \\
\text { (Web) }\end{array}$ & $\begin{array}{l}\text { Indian Citation Index, } \\
\text { NAAS, EBSCO } \\
\text { Discovery, Summon } \\
\text { (ProQuest ), Google } \\
\text { Scholar etc. }\end{array}$ & $\begin{array}{l}\text { University } \\
\text { Library } \\
\text { Teacher's } \\
\text { Association of } \\
\text { Andhra } \\
\text { Pradesh, } \\
\text { Hyderabad } \\
\end{array}$ & 44 & 470 \\
\hline 05 & $\begin{array}{l}\text { SRELS } \\
\text { Journal of } \\
\text { Information } \\
\text { Management }\end{array}$ & $\begin{array}{l}0972-2467 \\
\text { (Print) } \\
0976-2477 \\
\text { (Online) }\end{array}$ & I-Scholar, J-Gate, & $\begin{array}{l}\text { Sarada } \\
\text { Ranganathan } \\
\text { Endowment for } \\
\text { Library } \\
\text { Science, } \\
\text { Bangalore } \\
\end{array}$ & 64 & 616 \\
\hline & & & & & 262 & 2414 \\
\hline
\end{tabular}

\section{Subject Wise Analysis of the Articles}

The 2414 articles published in the top five Indian LIS journals were analyzed according to their subjects. Table 2 reveals the data about subject wise articles published in the top five Indian LIS journals during the period of 2009-2019. It is clear from table 2 that ICT, Information Science and Bibliometrics/Scientometrics/Webometrics were the preferred topics by the authors for writing research papers in the journals. Whereas very less number of articles were published on the topic classification and cataloguing.

Table 2: Subject Wise Analysis of the Articles

\begin{tabular}{|c|l|c|c|c|c|c|c|}
\hline \multirow{2}{*}{ S.N Subject } & \multicolumn{5}{c|}{ Name of the Journal } \\
\cline { 3 - 9 } & & Alis & Desidoc & $\begin{array}{l}\text { Library } \\
\text { Herald }\end{array}$ & Pearl & Srels & Total \\
\hline 01 & ICT & 82 & 264 & 73 & 178 & 213 & $\mathbf{8 1 0}$ \\
\hline 02 & Information Science & 131 & 134 & 95 & 92 & 145 & $\mathbf{5 9 7}$ \\
\hline 03 & Bibliometric/Scientometric/Webometric & 72 & 86 & 123 & 31 & 73 & $\mathbf{3 8 5}$ \\
\hline 04 & Library Management & 29 & 52 & 40 & 107 & 92 & $\mathbf{3 2 0}$ \\
\hline 05 & Digitization & 6 & 27 & 8 & 24 & 31 & $\mathbf{9 6}$ \\
\hline 06 & Education & 13 & 16 & 12 & 24 & 2 & $\mathbf{6 7}$ \\
\hline 07 & Automation & 2 & 13 & 6 & 9 & 9 & $\mathbf{3 9}$ \\
\hline 08 & Classification & 11 & 5 & 1 & 0 & 9 & $\mathbf{2 6}$ \\
\hline
\end{tabular}




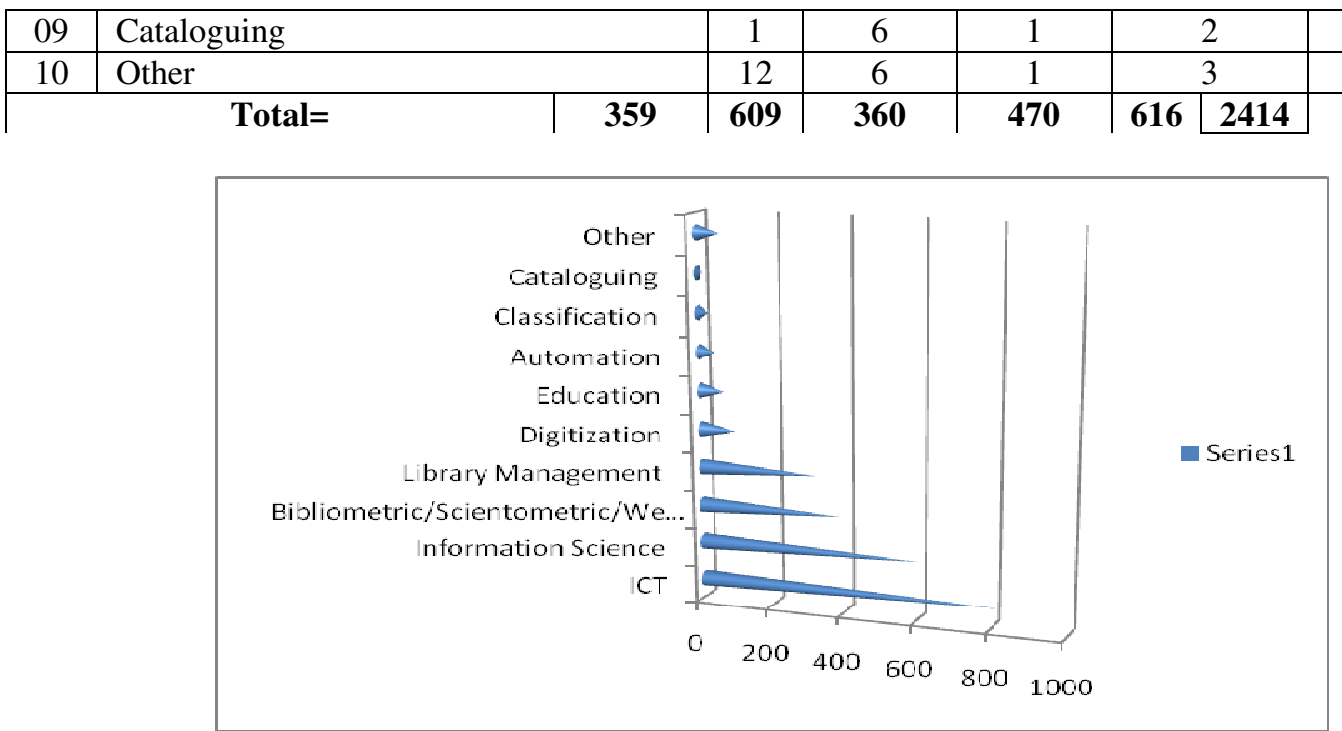

Figure 1

\section{Authorship Pattern}

Efforts were made to know the authorship pattern of the published articles. Table 3 contains the data regarding authorship pattern of the published articles. It can be seen from the table 3 that double authorship pattern was found popular for publishing research papers in the journals and it was followed by single author and three authors pattern respectively.

Table 3: Authorship Pattern

\begin{tabular}{|c|l|c|c|c|c|c|}
\hline $\begin{array}{c}\text { S. } \\
\mathbf{N}\end{array}$ & \multicolumn{1}{|c|}{ Name of the Journal } & $\begin{array}{c}\text { Single } \\
\text { Author }\end{array}$ & $\begin{array}{c}\text { Double } \\
\text { Author }\end{array}$ & $\begin{array}{c}\text { Three } \\
\text { Author }\end{array}$ & $\begin{array}{c}\text { More Than } \\
\text { Three Authors }\end{array}$ & Total \\
\hline 01 & ALIS & 123 & 168 & 53 & 15 & $\mathbf{3 5 9}$ \\
\hline 02 & $\begin{array}{l}\text { DESIDOC Journal of Library \& } \\
\text { Information Technology }\end{array}$ & 195 & 285 & 95 & 34 & $\mathbf{6 0 9}$ \\
\hline 03 & Library Herald & 196 & 121 & 34 & 9 & $\mathbf{3 6 0}$ \\
\hline 04 & $\begin{array}{l}\text { PEARL Journal of Library and } \\
\text { Information Science }\end{array}$ & 183 & 215 & 60 & 12 & $\mathbf{4 7 0}$ \\
\hline 05 & $\begin{array}{l}\text { SRELS Journal of Information } \\
\text { Management }\end{array} \quad 201$ & 313 & 82 & 20 & $\mathbf{6 1 6}$ \\
\hline \multicolumn{2}{|}{ Total= } & $\mathbf{8 9 8}$ & $\mathbf{1 1 0 2}$ & $\mathbf{3 2 4}$ & $\mathbf{9 0}$ & $\mathbf{2 4 1 4}$ \\
\hline
\end{tabular}

\section{LIS Doctoral Research: Statewide Contribution on Shodhganga}

Efforts were made to find out the LIS doctoral thesis uploaded on Shodhganga ETD by the Indian Universities. The 1288 LIS doctoral thesis having thesis submission year between 2009-2019 were searched and sorted according to the state of the submitting university. Table 4 contains the data regarding state wide LIS doctoral thesis uploaded Shodhganga ETD having thesis submission year between 2009-2019. It can be seen from the table 4 that Tamil Nadu state of the India have uploaded highest number of LIS thesis (thesis submission year between 2009-2019) on Shodhganga ETD.

Table 4: LIS Doctoral Thesis on Shodhganga EDT: State Wide Contribution

\begin{tabular}{|c|l|c|}
\hline Sr No. & \multicolumn{1}{|c|}{ State } & No of Thesis \\
\hline 1 & Tamil Nadu & 353 \\
\hline 2 & Karnataka & 159 \\
\hline 3 & Maharashtra & 155 \\
\hline 4 & Uttar Pradesh & 88 \\
\hline 5 & Gujrat & 84 \\
\hline
\end{tabular}




\begin{tabular}{|c|l|c|}
\hline \multicolumn{1}{|c|}{ Table 4: Contd,.. } & 74 \\
\hline \multicolumn{2}{|c|}{ West Bengal } \\
\hline 7 & Andhra Pradesh & 66 \\
\hline 8 & Assam & 49 \\
\hline 9 & Rajasthan & 34 \\
\hline 10 & Punjab & 24 \\
\hline 11 & Madhya Pradesh & 23 \\
\hline 12 & Haryana & 21 \\
\hline 13 & Meghalaya & 21 \\
\hline 14 & Mizoram & 21 \\
\hline 15 & Chhattisgarh & 20 \\
\hline 16 & Chandigarh & 17 \\
\hline 17 & Odisha & 17 \\
\hline 18 & Jammu and Kashmir & 15 \\
\hline 19 & Kerala & 15 \\
\hline 20 & Manipur & 14 \\
\hline 21 & New Delhi & 12 \\
\hline 22 & Telangana & 2 \\
\hline 23 & Puducherry & $\mathbf{1 2 8 8}$ \\
\hline & & Total= \\
\hline
\end{tabular}

\section{LIS Doctoral Research: Subject wise Analysis}

An attempt has made to analyze the LIS doctoral thesis uploaded on Shodhganga ETD by the Indian Universities. The 1288 LIS doctoral thesis having thesis submission year between 2009-2019 were analyzed according to their area of research. The 1288 thesis have been broadly categorized in to the 32 broad subject areas. The data is presented in descending order i.e. top ranked subjects to the less attracted area of LIS research. It can be revealed from table 5 that the subjects User Study, e-Resources and ICT attracted more number of research scholars towards them and it was followed by the Library Management and Bibliometrics / Scientometrics / Webometrics. The less attracted areas for research include Accreditation, Content Management and Classification.

Table 5: LIS Doctoral Thesis on Shodhganga ETD: Subject Wise Analysis

\begin{tabular}{|c|l|c|}
\hline Sr No. & \multicolumn{1}{|c|}{ Subject } & No of Thesis \\
\hline 1 & User Study & 199 \\
\hline 2 & e-Resources & 161 \\
\hline 3 & ICT & 161 \\
\hline 4 & Library Management & 154 \\
\hline 5 & Bibliometric/Scientometric/Webometric & 147 \\
\hline 6 & Library Services & 73 \\
\hline 7 & Digitization & 48 \\
\hline 8 & Public Library & 36 \\
\hline 9 & Academic Libraries & 35 \\
\hline 10 & Citation Analysis & 24 \\
\hline 11 & Information Literacy & 24 \\
\hline 12 & Library Network & 23 \\
\hline 13 & Web Resources & 21 \\
\hline 14 & Library Software & 20 \\
\hline 15 & Human Resource Management & 19 \\
\hline 16 & Library Automation & 17 \\
\hline 17 & Research Publication & 17 \\
\hline 18 & Special Library & 17 \\
\hline 19 & Library Science Education & 16 \\
\hline 20 & Other & 11 \\
\hline 21 & Content Analysis & \\
\hline
\end{tabular}




\begin{tabular}{|c|l|c|}
\hline 22 & Subject Development & 11 \\
\hline \multicolumn{2}{|c|}{ Table 5: Contd,. } \\
\hline 23 & Social Networking & 7 \\
\hline 24 & Knowledge Management & 6 \\
\hline 25 & Library Finance & 6 \\
\hline 26 & Library Movement & 5 \\
\hline 27 & IPR & 4 \\
\hline 28 & Indexing & 3 \\
\hline 29 & Information Retrieval & 3 \\
\hline 30 & Classification & 2 \\
\hline 31 & Content Management & 1 \\
\hline 32 & Accreditation & $\mathbf{1 2 8 8}$ \\
\hline
\end{tabular}

\section{LIS Doctoral Research: Top ten Universities on Shodhganga}

Efforts were made to find out the universities who have uploaded highest number of LIS thesis on Shodhganga ETD. The data regarding top ten universities who have uploaded highest number of LIS thesis is presented in table 6.

Table 6: LIS Doctoral Thesis on Shodhganga ETD: Top Ten Universities

\begin{tabular}{|c|l|l|c|}
\hline Sr No & \multicolumn{1}{|c|}{ Name of the University } & \multicolumn{1}{|c|}{ State } & No of Thesis \\
\hline 1 & Manonmaniam Sundaranar University, Tirunelveli & Tamil Nadu & 89 \\
\hline 2 & University of Mysore, Mysore & Karnataka & 60 \\
\hline 3 & Bharathiar University, Coimbatore & Tamil Nadu & 58 \\
\hline 4 & Aligarh Muslim University, Aligarh & Uttar Pradesh & 48 \\
\hline 5 & Sri Venkateswara University, Tirupati & Andhra Pradesh & 48 \\
\hline 6 & Bharathidasan University, Tiruchirapalli & Tamil Nadu & 46 \\
\hline 7 & Dr.BabasahebAmbedkarMarathwada University, Aurangabad & Maharashtra & 45 \\
\hline 8 & Alagappa University, Karaikudi & Tamil Nadu & 44 \\
\hline 9 & Gauhati University, Guwahati & Assam & 43 \\
\hline 10 & Tilak Maharashtra Vidyapeeth, Pune & Maharashtra & 39 \\
\hline
\end{tabular}

\section{FINDINGS}

The results of the study show that the subjects Information Communication Technology, Information Science and bibliometrics/scientometrics/webometrics attracted more authors for writing the research papers. Whereas user study, eResources and Information Communication Technology were the top ranking research areas chosen by the research scholars for their doctoral research. Manonmaniam Sundaranar University, Tirunelveli have uploaded highest number of LIS thesis on Shodhganga. The Universities from the states Tamilnadu, Karnataka and Maharashtra contributed highest number of LIS thesis on Shodhganga.

\section{REFERENCES}

1. Annals of Library and Information Studies. Retrieved from - http://nopr.niscair.res.in/handle/123456789/66.

2. Chandrashekhara, M.and Ramasesh, C.P.(2009). Library and Information Science Research in India. Asia -Pacific Conference on Library \& Information Education \& Practice, 2009.

3. BHATIA, KETKI. "Library \& Information Officer, National Institute of Occupational Health, Meghaninagar, Ahmadabad, India." IASET: International Journal of Library \& Educational Science (IASET: IJLES) 2. 2, Feb - Mar 2016, 1-12

4. Chauhan, S. K. \& Mahajan, P. (2017). Measuring Quality and Quantity of Indian Library and Information Science Research Output. SRELS Journal of Information Management. 54(3), 125-129. https://doi.org/10.17821/srels/2017/v54i3/79954. 
5. Hariharan, S., and M. Tamizhchelvan. "Ethics of Library Professionals' Relation with Organisation and Professionalism in Self Financing Engineering College Libraries in Tamilnadu." International Journal of Library Science and Research (IJLSR), $6(3), 3338$ (2016).

6. Bhatia, KETKI K., and M. A. Y. A. N. K. Trivedi. "MOOCS: PARADIGM SHIFT FOR LIBRARIES?." International Journal of Library \& Educational Science 4.4 (2015): 67-80.

7. DESIDOC Journal of Library \& Information Technology . Retrieved from- $\underline{\text { https://www.drdo.gov.in/desidoc-journal-library- }}$ information-technology.

8. Garg, K. C. \& Sharma, C. (2017). Bibliometrics of Library and Information Science research in India during 2004-2015. DESIDOC Journal of Library \& Information Technology. 37(3), 221-227. https://doi.org/10.14429/djlit.37.3.11188

9. Iqbal, Peerzada Mohammad, and Abdul Majid Baba. "Currency of Research Articles for Select Major Search Engines in the Field of Library \& Information Science." IASET: International Journal of Library \& Educational Science (IASET: IJLED) 2.2 (2016): 61-70.

10. Hodonu-Wusu, J. O., \& Lazarus, G. N. (2018). Major Trends in LIS Research: A Bibliometric Analysis. Library Philosophy \& Practice. $1-21$.

11. Khanchandani, Vanita. (2019). LIS education in India : Emerging trends and challenges. Library Herald. Vol.57 (03), $315-$ 326.

12. Thamaraiselvi, G. "Dissemination of Information Through cloud computing services in academic Libraries." IASET: International Journal of Library \& Educational Science 1.1 (2015).

13. Khumbar, Debbarma \& K. Praveen. (2019). LIS education in India with the emerging trends in libraries: Opportunities and challenges. Indian Journal of Information Sources and Services. Vol.09 (S1), 41-43.

14. Library Herald. Retrieved from - https://www.indianjournals.com/ijor.aspx?target=ijor:lh\&type=home.

15. M., Vijayakumar \& Kolle, S. R. (2017). Indian Contribution in Information Science and Library Science Research during 1991-2015: A Bibliometric Analysis. DESIDOC Journal of Library \& Information Technology. 37(6), 387-395. https://doi.org/10.14429/djlit.37.6.11005

16. Tripathi, Richa. "Utilization of Information Sources, by Research Scholars of Selected Universities in Chennai: A Study." International Journal of Humanities and Social Sciences (IJHSS) Vol 7 (2018): 35-40.

17. Maharana, R. K. \& Das, A. K. (2014). Growth and Development of LIS Research in India during 1999-2013: A Bibliometric Analysis. Chinese Librarianship. 37, 35-46.

18. Mittal, Rekha. (2011).Library and information science research trends in India. Annals of Library and Information Studies. Vol.58 (04), 319-325.

19. Onyancha, O. B. (2018). Forty-Five Years of LIS Research Evolution, 1971-2015: An Informetrics Study of the AuthorSupplied Keywords. Publishing Research Quarterly.34(3), 456-470. https://doi.org/10.1007/s12109-018-9590-3.

20. PEARL Journal of Library and Information Science. Retrieved from https://www.indianjournals.com/ijor.aspx?target=ijor:pjolis\&type=home.

21. Singh, Joginder. (2018). Scenario of the development of Library and Information Schools and current research trends in North India. International Journal of Library and Information Science. Vol.7(1), 47-62. 
22. Singh, S. P. \& Babbar, P. (2014). Doctoral Research in Library and Information Science in India: Trends and Issues. DESIDOC Journal of Library \& Information Technology. 34(2), 170-180. https://doi.org/10.14429/djlit.34.6019.

23. SRELS Journal of Information Management. Retrieved from - http://www.srels.org/. 